\title{
EUROPEAN ORCHID CULTIVATION - FROM SEED TO MATURE PLANT
}

\author{
JAN PONERT ${ }^{1,2, *}$, STANISLAV VOSOLSOBË ${ }^{1}$, \\ KATEŘINA KMECOVÁ ${ }^{1}$, and HELENA LIPAVSKÁ ${ }^{1}$ \\ ${ }^{1}$ Department of Experimental Plant Biology, Faculty of Science, Charles University in Prague, Viničná 5, 12844 Praha 2, \\ Czech Republic \\ 2 Prague Botanical Garden, Nádvorní 134, 17100 Praha 7 - Troja, Czech Republic \\ * Corresponding author: ponert@natur.cuni.cz; Tel.: +420 734366 417; Fax: +420 233542629
}

\section{ABSTRACT}

We describe a method for growing orchids of the genera Dactylorhiza and Ophrys, two European members of the subfamily Orchidoideae, from seeds to mature plants using asymbiotic in vitro cultures and glasshouse pot cultures. Four media were used: two new media 1/4-2 and Mo2 and two modifications of Michl medium (Michl 1988). We also describe a highly efficient technique for seed disinfection using a syringe. We tested the effects of ethanol treatment on Anacmaptis morio (L) R. M. Bateman, Pridgeon \& M. W. seeds, sugar media composition on Dactylorhiza majalis (Rchb.) P. F. Hunt \& Summerh., Oeceoclades decaryana (H. Perrier ex Guillaumin \& Manguin) Garay \& Taylor and Ophrys lojaconoi P. Delforge and the effect of kinetin on Dactylorhiza majalis protocorm growth. Sucrose was the best carbon source, while hexose resulted in the inhibition of protocorm development at early stages. The addition of kinetin at $10 \mathrm{mg} / \mathrm{l}$ resulted in the formation of the largest protocorms. Ethanol can have positive effect on seed germination when applied for a short time ( 2 min), while long-time ethanol exposure $(60 \mathrm{~min})$ can kill the seeds.

Keywords: in vitro cultivation, sowing, sugars, ethanol, kinetin

\section{Introduction}

Many plant species are become rare globally and many orchid species are endangered due to their mostly special ecological requirements. Orchid conservation and restoration efforts including the development of effective conservation techniques, are urgently needed. Although orchids comprise nearly one tenth of all plant species (Rasmussen and Rasmussen 2009), few orchid species are successfully grown from seeds and most that have been propagated from seeds are tropical epiphytical species. Temperate terrestrial orchids are more difficult to propagate and cultivate than tropical epiphytes (see Rasmussen 1995). In this study we have focused mainly on species of Dactylorhiza and Ophrys, two primarily European genera with differing ecological strategies.

Seeds of Dactylorhiza species have been successfully sterilized with $0.3 \% \mathrm{NaOCl}$ for 45 minutes (Frosh 1982), with $5 \% \mathrm{NaOCl}$ for 6 minutes (Rasmussen 1995) or with $5 \% \mathrm{Ca}(\mathrm{OCl})_{2}$ solution for 6 to 10 hours (Van Waes 1984). Many different media have been used to cultivate species of Dactylorhiza: Pfeffer-glucose medium (Hadley 1982), Chang medium (Harbeck 1968), Ramin medium (Galunder 1986), modified Knudson B medium, where urea proved to be better nitrogen source compared to ammonium (Vermeulen 1947).

Germination (Van Waes 1984; Rasmussen et al. 1990; Rasmussen and Rasmussen 1991) and protocorm growth (Van Waes 1984; Malmgren 1988) of Dactylorhiza species seemed to be inhibited by light, but in one case (Dactylorhiza majalis, higher germination rates was reported for seeds incubated in light and subsequently transferred to darkness compared to those grown in dark all the time (Rasmussen et al. 1990).

During seedling growth, the problems have been reported with phenolic compound exudation and seedling browning (Harbeck 1968; Haas 1977). This might be intensified by light, high temperatures and oxidizing substances as $\mathrm{Fe}^{3+}$ (Haas 1977), but reduced by transferring cultures to darkness or by frequent subcultivation onto new media (Harbeck 1968).

The seeds of different Ophrys species have been successfully disinfected with $0.3 \% \mathrm{NaOCl}$ for 45 minutes (Frosh 1982), with $0.2 \% \mathrm{NaOCl}$ for 10 minutes followed by $3-5 \% \mathrm{H}_{2} \mathrm{O}_{2}$ treatment for 10 minutes (Lucke 1971) or with $5 \% \mathrm{Ca}(\mathrm{OCl})_{2}$ for 4 hours (Van Waes and Debergh 1986a). Successful germinations have been reported on various media as Pfeffer-glucose medium, Norstog medium, Ramin medium, Mead and Bulard medium, Curtis medium (Hadley 1982b; Pritchard 1985a; Galunder 1986; Muir 1989; Barroso et al. 1990). However, germination percentages vary among studies - from reports about difficult Ophrys germination (Veyret 1969) to reports about easy germination up to 90\% (Borris and Albrecht 1969; Malmgren 1989b; Malmgren 2011). The procedures that have been used to germinate Ophrys seeds are very heterogeneous and, to the best of our knowledge, searching for any correlation between particular treatments and germination percentage has not been successful.

Our main goal is to present seed sowing and plant cultivation methods that we have been used with great success for the temperate genus Dactylorhiza and European mediterranean species represented by the genus Ophrys. In addition, some results achieved with other 
orchid species are presented to illustrate possible further application of the methods that we have used for species of Dactylorhiza and Ophrys.

\section{Material and methods}

\section{Seed collection and storage}

Whole seedpods were collected from mature plants when the first rupture of pod was visible, put into paper bags and stored under dry and dark conditions at room temperature. After drying, the seeds were cleaned from pod residues and other impurities using tweezers and then stored in paper bags under dry and dark conditions at room temperature until sowing.

\section{Seed sowing}

Seeds were sterilized in Luer plastic syringes, either 2 or $5 \mathrm{ml}$ depending on the amount of seed available for individual species. Level of seeds placed into the syringe should not exceed $0.5 \mathrm{ml}$ and $1 \mathrm{ml}$ mark in the $2 \mathrm{ml}$ and $5 \mathrm{ml}$ syringe, respectively, otherwise they block syringe and solutions replacement is difficult. Fig. 1 shows the configuration that was used for the syringes. Foam $(4 \times 4 \times 5 \mathrm{~mm})$ or nylon mesh $(1.5 \times 1.5 \mathrm{~cm})$ pieces were placed into the $1.2 \times 40\left(18 \mathrm{Gx} 11 / 2^{\prime \prime}\right.$, Luer-Lock; Dispomedicor Rt., Hungary) needle hub. The syringes were than fitted with these needles. Once the apparatus had been assembled, the plunger was removed and seeds were placed into it using a longitudinally folded piece of paper. After seeds had been added the plungers were pushed in the syringes. Prepared apparatus enable us to change solutions with seeds remaining inside the syringe.

In methods described previously (Ježek 1996) it was recommended to use thin needle as a filter that prevented passage of seeds as they were bigger than needle diameter. In our conditions the seeds often choke up the needle. In this case it is impossible to work with the seeds or a very high pressure can be reached during trying to loosen them. This pressure can (often in combination with toxic disinfection solution) kill the seeds (Ponert unpublished; Mácha pers. comm.). For this reason we exchanged a thin needle for a wide one supplemented with a filter (the piece of foam or nylon mesh). Foam is better for higher

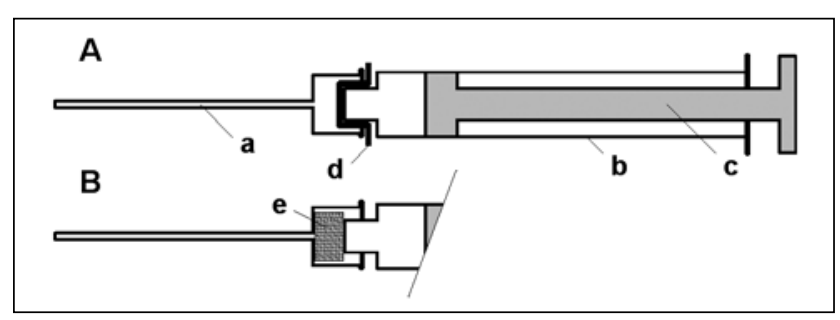

Fig. 1 Sowing apparatus. A) variant with nylon mesh, B) variant with foam. $a$ - needle, $b$ - syringe, $c$ - plunger, $d$ - nylon mesh, $e-$ foam. amount of seeds, because it is easy to work with, but some seeds snarled up in it and are lost. Nylon mesh is better for lower amount of seeds because nearly no seeds are captured within filter and as a result almost all seeds can be sown.

\section{Seed disinfection}

For seed disinfection a $70 \%$ ethanol solution was sucked into the syringe (up to half the volume of the syringe), the syringe shaken and the solution removed after 1-5 minutes. A series of solutions for disinfection and washing were applied as follows:

- Three washing with distilled water

- $2 \% \mathrm{H}_{2} \mathrm{SO}_{4}$ : 10 minutes; for selected seeds only (according to Malmgren 2011)

- Disinfection solution $\left(\mathrm{Ca}(\mathrm{OCl})_{2}\right.$ or $\mathrm{NaOCl}$ aqueous solution, 2.5 or 5\%): 3-30 minutes; once or twice during this step the solution was replaced - this greatly enhanced efficiency of the procedure

- Three washing with sterile (autoclaved) distilled water

- Resuspending in 1-5 ml of sterile distilled water (according to seed quantity).

Particular conditions used for each species are given in Table 1. For the study of sugar and cytokinin effect on protocorm growth seeds were treated by $70 \%$ ethanol for 5 minutes and $5 \% \mathrm{Ca}(\mathrm{OCl})_{2}$ solution for 10 minutes.

Ethanol was used as an initial step for better soaking of seeds (Michl 1988; Ježek 1996). Perhaps it washed out waxes (and some others hydrophobic substances) from seed coat. Thus the seeds became slightly more hydrophilic and it was much easier to work with them. After appropriate time, ethanol was washed out by distilled water and disinfection solution applied. To prepare $\mathrm{Ca}(\mathrm{OCl})_{2}$ disinfection solution $50 \mathrm{~g}$ of $\mathrm{Ca}(\mathrm{OCl})_{2}$ powder was mixed (and partially dissolved) in $100 \mathrm{ml}$ of distilled water and after 15 to 20 minutes filtrated through paper to a new flask. This solution contains approximately $5 \% \mathrm{OCl}^{-}$(determined by iodometric titration, data not shown). $\mathrm{NaOCl}$ was used as commercially available solution (approximately 5\% solution of $\mathrm{OCl}^{-}$; "household bleach") or diluted twice. Basicity of treatment solutions was determined by $\mathrm{pH}$-meter. Mean basicity was 12.5 and 11.4 for $\mathrm{NaOCl}$ and $\mathrm{Ca}(\mathrm{ClO})_{2}$ solutions, respectively. In some experiments (Tables 2-4), $\mathrm{pH}$ of the solutions was adjusted by addition of natrium hydroxide or hydrochloric acid.

\section{Seed sowing}

For sowing, the $1.2 \times 20$ needle was replaced with a sterile needle $1.8 \times 40\left(15 \mathrm{G} \times 11 / 2^{\prime \prime}\right.$; Luer-Lock; Dispomedicor Rt, Hungary) in a flow box. The seeds in the syringe were shaken to obtain homogeneous suspension and then immediately extruded onto solid medium in Petri dish (approximately 0.3 to $0.4 \mathrm{ml}$ of suspension per $6 \mathrm{~cm}$ plate containing up to several hundreds of seeds). 
Table 1 List of other performed sowings.

Pretreatment: $2-5$ min $70 \%$ ethanol; cooling: no

\begin{tabular}{|c|c|c|c|c|c|}
\hline Genus & Species & origin & $5 \% \mathrm{Ca}(\mathrm{OCl})_{2}[\mathrm{~min}]$ & Medium & Germination [\%] \\
\hline \multirow{3}{*}{ Anacamptis } & coriophora & Albania & 15 & Michl-15 & 80 \\
\hline & laxiflora & culture & 5 & $1 / 4-2$ & 75 \\
\hline & pyramidalis & Albania & 5 & Michl-15 & 50 \\
\hline \multirow{8}{*}{ Dactylorhiza } & foliosa & culture & 6 & $1 / 4-2$ & 30 \\
\hline & incarata & Czech Republic & 6 & $1 / 4-2$ & 0 \\
\hline & incarnata agg. & Czech Republic & 6 & $1 / 4-2$ & 80 \\
\hline & maculata s.s. & Czech Republic & 6 & $1 / 4-2$ & 80 \\
\hline & sambucina & Croatia & 5 & $1 / 4-2$ & 90 \\
\hline & sambucina & Croatia & 5 & Mo2 & 90 \\
\hline & sudetica & Czech Republic & 10 & Michl-15 & 10 \\
\hline & viridis & Montenegro & 10 & Michl-15 & 1 \\
\hline Disa & sagittalis & Culture & 15 & Mo2 & 90 \\
\hline Eulophia & petersii & South Africa & 15 & $1 / 4-2$ & 20 \\
\hline \multirow{2}{*}{ Gennaria } & diphylla & Corsica & 5 & Mo2 & 95 \\
\hline & diphylla & Corsica & 5 & $1 / 4-2$ & 95 \\
\hline Gymnadenia & conopsea & Czech Republic & 8 & $1 / 4-2$ & $15^{*}$ \\
\hline \multirow{2}{*}{ Himantoglossum } & caprinum & Albania & 10 & Michl-15 & 100 \\
\hline & robertianum & Italy & 10 & $1 / 4-2$ & 80 \\
\hline Listera & ovata & Czech Republic & 7 & $1 / 4-2$ & 2 \\
\hline \multirow{2}{*}{ Neotinea } & maculata & Greece & 6 & $1 / 4-2$ & 80 \\
\hline & ustulata & Czech Republic & 15 & Mo2 & 1 \\
\hline Oeceoclades & decaryana & culture & 10 & $1 / 4-2$ & 100 \\
\hline \multirow{6}{*}{ Ophrys } & apifera & Culture & 4 & $1 / 4-2$ & 20 \\
\hline & cilentana & Italy & 11 & $1 / 4-2$ & 95 \\
\hline & cilentana & Italy & 11 & Mo2 & 95 \\
\hline & insectifera & Czech Republic & 6 & $1 / 4-2$ & 85 \\
\hline & insectifera & Czech Republic & 6 & Mo2 & 85 \\
\hline & Iojaconoi & Italy & 10 & $1 / 4-2$ & 90 \\
\hline \multirow{3}{*}{ Orchis } & italica & Italy & 10 & Mo2 & 10 \\
\hline & provincialis & Corsica & 10 & Michl-15 & 100 \\
\hline & purpurea & Albania & 5 & Michl-15 & 30 \\
\hline Pleione & maculata $\times$ praecox & culture & 5 & $1 / 4-2$ & 5 \\
\hline \multirow{2}{*}{ Serapias } & $s p$. & Corsica & 6 & Mo2 & 100 \\
\hline & $s p$. & Corsica & 6 & $1 / 4-2$ & 100 \\
\hline Stenoglottis & fimbriata & culture & 10 & $1 / 4-2$ & 95 \\
\hline
\end{tabular}

*) additional pretreatment with $2 \% \mathrm{H}_{2} \mathrm{SO}_{4}$ for 10 min before hypochlorite treatment and cooling for 2 month necessary

Then Petri dish was closed and seeds spread on the medium surface by slight horizontal gyration. Remaining water easily soaked into agar medium. The Petri dishes were sealed by at least double layer of parafilm and placed in dark at temperature $23^{\circ} \mathrm{C}$ or $2^{\circ} \mathrm{C}$.

\section{In vitro culture}

We used 4 different media for sowing seeds: 1/4-2, Mo2, Michl-15 and Michl-16. 1/4-2 and Mo2 media were developed by our team for terrestrial orchids culture as described previously (Ponert 2009). Michl-15 and Michl-16 are modified Michl media (Michl 1988). We excluded glucose because of its inhibitory effect on seed germination of some orchid species (see Results - Fig. 4). Medium Michl-15 has lower osmotic activity and was used only for germination. Michl-16 was used for subsequent seedling cultivation. All media components were mixed before autoclaving (unless otherwise indicated). After autoclaving, the medium was stirred by horizontal gyration before agar solidification to avoid charcoal sedimentation.

Following the sowings in plastic Petri dishes were kept in the dark until protocorms of adequate size developed. Appropriate protocorm size for transplanting was de- 
Table 2 Comparison of natrium and calcium hypochlorite treatments at different solution basicity.

\begin{tabular}{|l|c|c|c|c|}
\hline \multicolumn{4}{|l|}{ Species: Dactylorhiza majalis (Czech Republic) } \\
\hline $\begin{array}{l}\text { Pretreatment: } 2 \text { min } 70 \% \text { ethanol; medium: Michl-15; } \\
\text { cooling: no; replications: } 3\end{array}$ \\
\hline \multirow{2}{*}{ Treatment } & \multicolumn{5}{|c|}{ Germination rate [\%] } \\
\cline { 2 - 5 } & $\mathbf{5 \%} \mathbf{~ N a O C l}$ & $\mathbf{5 \%} \mathbf{C a}\left(\mathbf{O C l} \mathbf{2}_{\mathbf{2}}\right.$ \\
\hline $\mathrm{pH}$ & 11.4 & 12.5 & 11.4 & 12.5 \\
\hline $5 \mathrm{~min}$ & $1 \pm 1$ & $1 \pm 1$ & $49 \pm 11$ & $62 \pm 9$ \\
\hline $10 \mathrm{~min}$ & 0 & $1 \pm 1$ & $71 \pm 14$ & $33 \pm 10$ \\
\hline $20 \mathrm{~min}$ & 0 & 0 & $65 \pm 13$ & $2 \pm 1$ \\
\hline
\end{tabular}

Table 3 Effect of natrium hypochrorite treatment solution basicity.

\begin{tabular}{|c|c|c|c|c|}
\hline \multicolumn{5}{|c|}{ Species: Orchis spitzelii (Albania) } \\
\hline \multicolumn{5}{|c|}{$\begin{array}{l}\text { Pretreatment: } 2 \text { min } 70 \% \text { ethanol; medium: Michl-15; } \\
\text { cooling: no; replications: } 3\end{array}$} \\
\hline \multirow{2}{*}{\begin{tabular}{|l|} 
Treatment \\
$\mathrm{NaOCl}$ \\
\end{tabular}} & \multicolumn{4}{|c|}{ Germination rate [\%] } \\
\hline & \multicolumn{2}{|c|}{$2.5 \%$} & \multicolumn{2}{|c|}{$5 \%$} \\
\hline $\mathrm{pH}$ & 10.4 & 12.5 & 10.4 & 12.5 \\
\hline $3 \mathrm{~min}$ & $52 \pm 19$ & 0 & 0 & 0 \\
\hline $8 \mathrm{~min}$ & $1 \pm 1$ & 0 & 0 & 0 \\
\hline $15 \mathrm{~min}$ & 0 & 0 & 0 & 0 \\
\hline
\end{tabular}

Table 4 Effect of different $\mathrm{pH}$ and concentration of natrium hypochlorite solution and cooling $\left(2^{\circ} \mathrm{C}\right)$ after sowing on germination.

\begin{tabular}{|c|c|c|c|c|}
\hline \multicolumn{5}{|c|}{ Pretreatment: 2 min $70 \%$ ethanol; medium } \\
\hline \multicolumn{5}{|c|}{ Species: Dactylorhiza cordigera (Albania) } \\
\hline Treatment & \multicolumn{4}{|c|}{ Germination rate [\%] } \\
\hline $\mathrm{NaOCl}(3 \mathrm{~min})$ & \multicolumn{2}{|c|}{$2.5 \%$} & \multicolumn{2}{|c|}{$5 \%$} \\
\hline $\mathrm{pH}$ & 10.4 & 12.5 & 10.4 & 12.5 \\
\hline 2 month cooling & $98 \pm 2$ & $95 \pm 3$ & $12 \pm 5$ & $9 \pm 4$ \\
\hline not cooled & $97 \pm 2$ & $96 \pm 3$ & $42 \pm 15$ & Contamined \\
\hline \multicolumn{5}{|c|}{ Species: Orchis purpurea (Czech Republic) } \\
\hline Treatment & \multicolumn{4}{|c|}{ Germination rate [\%] } \\
\hline $\mathrm{NaOCl}(3 \mathrm{~min})$ & \multicolumn{2}{|c|}{$2.5 \%$} & \multicolumn{2}{|c|}{$5 \%$} \\
\hline $\mathrm{pH}$ & 10.4 & 12.5 & 10.4 & 12.5 \\
\hline 2 month cooling & $6 \pm 2$ & $11 \pm 4$ & $5 \pm 3$ & $1 \pm 1$ \\
\hline not cooled & 0 & 0 & 0 & 0 \\
\hline
\end{tabular}

fined as as rounded protocorm that had produced a small shoot tip (approximately 2 to $7 \mathrm{~mm}$ protocorm diameter according to species). The protocorms were transplanted into $100 \mathrm{ml}$ Erlenmayer flasks or square Petri-dishes $(12 \times 12 \mathrm{~cm})$ with $50 \mathrm{ml}$ of solid medium, sealed with aluminum foil or parafilm respectively. Developed young plants were cultivated under light (1000 lux). Seedlings were transplanted only when the plants are too big, too dense or started to brown (approx after 3 to 12 months). Cultivation of protocorms in flasks and petri dishes was done at temperatures of $17^{\circ} \mathrm{C}$ or $20^{\circ} \mathrm{C}$ and a photoperiod of 16 hours. The protocorms of Dactylorhiza maculata (L.) Soó, D. sambucina (L.) Soó and Neotinea maculata
(Desf.) Stearn were cultivated at $4{ }^{\circ} \mathrm{C}$ for three months before transplanting.

\section{Deflasking}

When the plants became sufficiently large, the flasks were opened, the plants were taken up with tweezers, washed under running cold tap water to remove medium residues and potted into a substrate. For Dactylorhiza species (D. maculata (L.) Soó, D. bohemica Businský, $D$. baltica (Klinge) N. I. Orlova) we used plastic pots filled with mixture of peat (Lithuanian) and pumice gravel (grain size approx. $3 \mathrm{~mm}$ ) in a ratio $1: 1.5$. For mediterranean plants (Ophrys spp, Anacamptis spp) we used clay pots filled with mixture of pumice gravel (grain size approx. $3 \mathrm{~mm}$ ), Seramis, horticultural perlite (not fine) and a clay soil from natural calcareous areas (in our case mostly Prokopské údolí in Prague) in a ratio $1: 1: 1: 0.2$. The clay pots were placed into a sand bed to avoid excessive drying out. All pots were with a drainage layer of coarse pumice gravel at the bottom - approx. $2 \mathrm{~cm}$ for clay pots and $4 \mathrm{~cm}$ for the plastic ones. After potting, the plants were watered (tap water modified by reverse osmosis to conductivity $75 \mu \mathrm{S}, \mathrm{pH}$ approximately 6.5 ) and cultivated in a glasshouse under the same conditions as mature plants.

\section{Glasshouse plant culture}

The plants were cultivated in an aboveground glasshouse on tables (Sekerka et al. 2007). Temperature was $2-10 / 0.5-3{ }^{\circ} \mathrm{C}$ (day/night) during winter and when no frosts occurred, ventilation was automatically opened at maximum level. During summer, glasshouse cultivation led to slightly higher temperatures. Dactylorhiza species were watered once per day to avoid drying out. For mediterranean plants the regime was adjusted according to their growth cycle. During the growing season (winter), the plants were watered approximately twice per week according to weather to avoid absolute drying out but also excessive wetting. During summer dormancy, the pots were watered only slightly, approximately once per month. Repotting was done every year into a new substrate during the end of summer dormancy (August-September). The list of all mature plants that have been successfully grown under these conditions is given in Table 5.

\section{Ethanol effect on germination}

The seeds of Anacamptis morio (L.) R. M. Bateman, Pridgeon and M. W. Chase were disinfected by the procedure described above, but without any hypochlorite treatment, only with $70 \%$ ethanol for different time intervals $(2,5,15$, and 60 minutes). Then they were sowed on medium Michl-15 without organic compounds (to reduce contamination development, no effect of this 
Table 5 Orchid species which are grown by presented method as mature plants.

\begin{tabular}{|c|c|c|}
\hline Region & Genus & Species \\
\hline \multirow{9}{*}{ Europe } & Anacamptis & fragrans, laxiflora, morio, papilionacea \\
\hline & Dactylorhiza & baltica, bohemica, fuchsii, incarnata, maculata, majalis, saccifera, traunsteinerii hybr., umbrosa \\
\hline & Epipactis & palustris \\
\hline & Gennaria & diphylla \\
\hline & Himantoglossum & caprinum, robertianum \\
\hline & Ophrys & $\begin{array}{l}\text { apifera, bertoloniiformis, biscutella, cerastes, cilentana, ferrum-equinum, incubacea, lojaconoi, } \\
\text { lucana, lutea, macedonica, mammosa agg., passionis, phryganae, speculum, ulyssea, zeusii }\end{array}$ \\
\hline & Orchis & anthropophora, italica, pauciflora, provincialis, spitzelii \\
\hline & Serapias & cordigera, ionica, lingua, parviflora, strictiflora, vomeracea \\
\hline & Spiranthes & spiralis \\
\hline \multirow{3}{*}{ South Africa } & Disa & sagittalis \\
\hline & Holothrix & burchelii \\
\hline & Pterygodium & catholicum, erectum, ligulatum, pumilum \\
\hline Asia & Habenaria & davidii, glaucifolia \\
\hline \multirow{4}{*}{ Australia } & Caladenia & Harlequin, paludosa $x$ polychroma \\
\hline & Microtis & cf. atrata \\
\hline & Pterostylis & curta, pedunculata, toveyana \\
\hline & Thelymitra & (x dentata) $\times$ nuda, 'Kay Nesbitt', aff. macrophylla x luteocilleum, aff. holmesii, granitora, nuda \\
\hline
\end{tabular}

Table 6 Effect of hypochlorite treatment duration.

\begin{tabular}{|c|c|c|c|c|}
\hline \multicolumn{5}{|c|}{ Pretreatment: 2 min 70\% ethanol; medium: Michl-15; cooling: no; replications: 3} \\
\hline \multirow{2}{*}{ Species } & \multirow{2}{*}{ Treatment } & $5 \mathrm{~min}$ & $10 \mathrm{~min}$ & $15 \mathrm{~min}$ \\
\hline & & \multicolumn{3}{|c|}{ Germination rate [\%] } \\
\hline Anacamptis morio (Czech Republic) & $5 \% \mathrm{NaOCl}$ & $70 \pm 15$ & & $75 \pm 16$ \\
\hline Dactylorhiza bohemica (Czech Republic) & & $5 \pm 3$ & $5 \pm 2$ & \\
\hline Ophrys cilentana (Italy) & & $40 \pm 30$ & & 0 \\
\hline Anacamptis papilionaceae (Albania) & $5 \% \mathrm{Ca}(\mathrm{OCl})_{2}$ & $95 \pm 4$ & $96 \pm 5$ & \\
\hline Dactylorhiza baltica (Lithuania) & & $5 \pm 2$ & $1 \pm 1$ & \\
\hline Ophrys cilentana (Italy) & & & $85 \pm 9$ & \\
\hline Ophrys holubyana (Czech republic) & & $93 \pm 5$ & $92 \pm 6$ & \\
\hline Orchis mascula (Montenegro) & & $53 \pm 12$ & $70 \pm 15$ & $45 \pm 18$ \\
\hline Orchis spitzelii (Albania) & & $53 \pm 37$ & $89 \pm 11$ & $94 \pm 4$ \\
\hline
\end{tabular}

omission on germination was observed) and cultivated at $23{ }^{\circ} \mathrm{C}$, in the dark. The data on germination frequency were collected after four weeks of cultivation.

\section{Disinfection treatment testing}

For testing of different disinfection treatment effect on seed germination $2.5 \%$ and $5 \%$ aqueous solutions of $\mathrm{NaOCl}$ and $\mathrm{Ca}(\mathrm{OCl})_{2}$ were prepared. Seeds of different species (see Table 6 and 7) were firstly treated by $70 \%$ ethanol for 2 minutes, washed with distilled water and subsequently disinfected by hypochlorite solution for 5 , 10 , or 15 minutes. Seeds were sowed on Michl-15 medium and data on germination rate were collected after two months of culture.

For testing of different solution basicity effect $\mathrm{NaOCl}$ and $\mathrm{Ca}(\mathrm{OCl})_{2}$ solutions with modified $\mathrm{pH}$ were prepared.
Table 7 Comparison of calcium and natrium hypochlorite treatments at different concentrations and durations.

\begin{tabular}{|l|c|c|c|c|}
\hline \multicolumn{4}{|l|}{ Species: Dactylorhiza fuchsii (Czech Republic) } \\
\hline $\begin{array}{l}\text { Pretreatment: } 2 \text { min } 70 \% \text { ethanol; medium: Michl-15; } \\
\text { cooling: no; replications: } 3\end{array}$ \\
\hline \multirow{2}{*}{ Treatment } & \multicolumn{5}{|c|}{ Germination rate [\%] } \\
\cline { 2 - 5 } & \multicolumn{3}{|c|}{ NaOCI } & \multicolumn{2}{c|}{ Ca(OCI) } \\
\hline Concentration (\%) & 2.5 & 5 & 2.5 & 5 \\
\hline 5 min & $2 \pm 1$ & 0 & $13 \pm 4$ & 0 \\
\hline 10 min & $1 \pm 1$ & 0 & $28 \pm 9$ & $9 \pm 3$ \\
\hline
\end{tabular}

Native $\mathrm{pH}$ of these solutions is 12.5 for $\mathrm{NaOCl}$ and 11.5 for $\mathrm{Ca}(\mathrm{OCl})_{2}$ respectively. We prepared $\mathrm{NaOCl}$ solution with $\mathrm{pH} 11.5$ by adding $\mathrm{HCl}$ and $\mathrm{Ca}(\mathrm{OCl})_{2}$ solution with $\mathrm{pH} 12.5$ by adding $\mathrm{NaOH}$. The concentration of $\mathrm{ClO}^{-}$in 
solutions was determined by iodometry and adjusted for the same levels. Seeds of different species were treated as above (70\% ethanol: 2 minutes, distilled water, hypochlorite solution) and sowed on Michl-15 medium (for details see Tables 2, 3, and 4). Data on germination rate were collected after two months of culture.

Note, it was impossible to prepare true $\mathrm{Ca}(\mathrm{OCl})_{2}$ solution with $\mathrm{pH}$ 12.5. $\mathrm{NaOH}$ addition lead to the precipitation of $\mathrm{Ca}(\mathrm{OH})_{2}$ and resulted solution should be the same with the $\mathrm{NaOCl}$ one.

\section{Sugar effect on protocorm growth}

For testing of different sugar effects on protocorm growth the medium without organic supplements was used (Ponert 2009) so that the only C source was the sugar added. Five different treatments were tested: medium without any sugar, separately applied fructose, glucose or sucrose and medium with combination of glucose and fructose. Total sugar concentrations in the media were $100 \mathrm{mM}$ for hexoses and $50 \mathrm{mM}$ for sucrose. The seeds of three different species Dactylorhiza majalis (Rchb.) P. F. Hunt and Summerh., Oeceoclades decaryana (H. Perrier ex Guillaumin and Manguin) Garay and P. Taylor and Ophrys lojaconoi P. Delforge had been sown directly on media. The data on protocorm size were collected after three months of culture (unless otherwise stated).

\section{Cytokinin effect on protocorm growth}

For testing of cytokinin (kinetin and kinetin riboside) effect on protocorm growth, a medium without organic supplements (except for sugar) was used (Ponert 2009), so that the only phytohormone in the medium was cytokinin. Kinetin and kinetin riboside were diluted in ethanol, sterilized by filtration and added into medium after autoclaving to final concentrations $0.01,0.1,1,10$, and $100 \mathrm{mg} / \mathrm{l}$. The seeds of Dactylorhiza majalis (Rchb.) P. F. Hunt and Summerh. had been sown directly on media. The data on protocorm size were collected after 18 days and 2 months of culture.

\section{Data collection and analysis}

The developing cultures on Petri dishes were observed using a microscope (Olympus BX50 F4, magnification $4 \times$ ) or a digital camera with macro lens (Canon EOS 40D with Canon Macro EF 100 mm 1:2.8 USM), the photographs of protocorms taken (software: LuciaG5; camera Nikon Digital Sight DS-U1) and protocorm diameters measured. Statistical analyses were performed using R 2.9.1. (R Development Core Team 2009) or NCSS 97: Anova, Tukey-Kramer test (Kramer 1956) for data with normal distribution and Kruskall-Wallis test (Kruskal and Wallis 1952) for data which did not meet normality criteria.

\section{Results}

\section{Sowings}

Over a ten year period, we successfully germinated seeds of about forty orchid species (Table 1-6) and gained valuable information into the germination process as a result of our studies of several factors that influence germination.

\section{Effect of ethanol treatment on germination}

Ethanol resulted in slightly higher but not statistically significant germination percentages ( $80 \%$ comparing to $60-75 \%$ germination, but statistically not significant, Fig. 2). Longer times of disinfections, however, resulted in lower germination rates with no germination occurring in seeds that had been exposed to ethanol for 60 minutes (statistically different, Fig. 3).

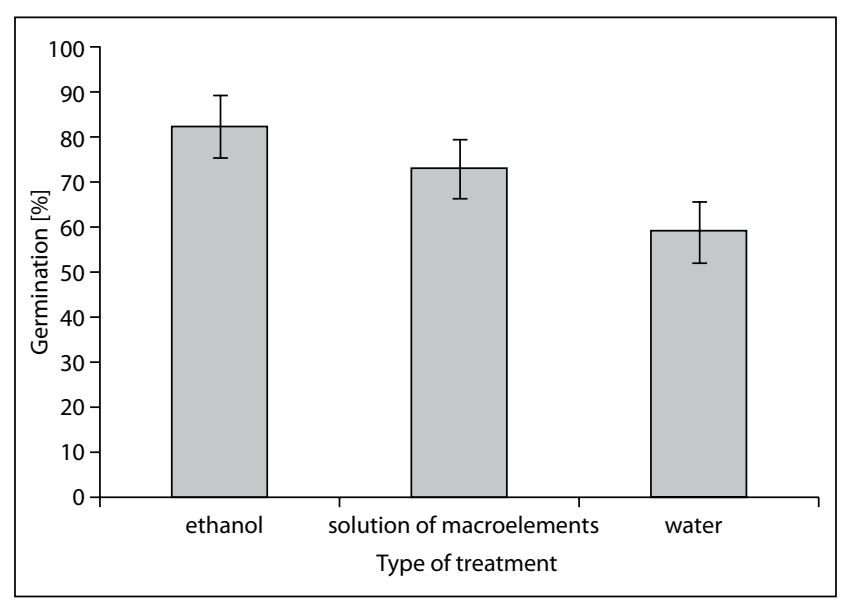

Fig. 2 Comparison of effects of ethanol, macronutrient solution and water treatments on Anacamptis morio seeds germination. Germination determined four weeks after sowing on macronutrient medium without saccharides.

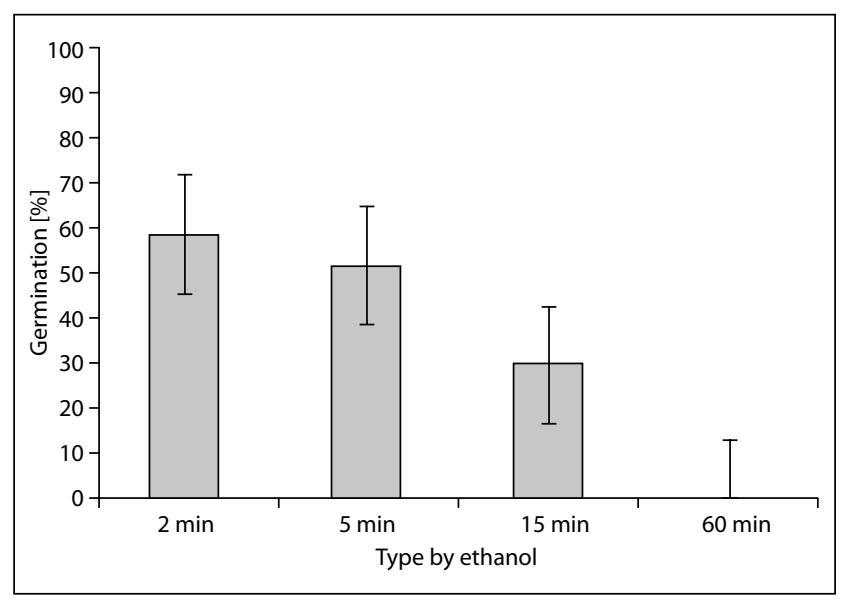

Fig. 3 Effect of ethanol treatment on Anacamptis morio seed germination. Germination determined four weeks after sowing on medium without saccharides. 


\section{Disinfection treatment testing}

The effects of disinfection solution and duration were heterogeneous among plant species (for illustrations see Table 6). $\mathrm{NaOCl}$ seems to be have a negative effect on germination of Dactylorhiza fuchsii (Table 7) and Dactylorhiza majalis (Table 4), but other species with the exception of Dactylorhiza baltica germinated well after this treatment (Table 6).

The effect of disinfection solution $\mathrm{pH}$ seems to be species specific. $\mathrm{Ca}(\mathrm{OCl})_{2}$, solution $\mathrm{pH}$ had a dramatic effect on Dactylorhiza majalis germination with the best result after 10 minutes of $\mathrm{Ca}(\mathrm{OCl})_{2}$, solution with $\mathrm{pH} 11.4$ (Table 2). $\mathrm{NaOCl}$ solution $\mathrm{pH}$ seems to have dramatic effect too. Orchis spitzelii germinated well only after 3 minutes of $2.5 \% \mathrm{NaOCl}$ solution with $\mathrm{pH} 10.4$ (Table 3), the best germination of Orchis purpurea was after 3 minutes of $2.5 \% \mathrm{NaOCl}$ solution with pH 12.5 (Table 4), while relatively weak effect of $\mathrm{NaOCl} \mathrm{pH}$ can be seen in Dactylorhiza cordigera (Table 4).

\section{Sugar effects on protocorm growth}

Suitability of different sugars to support germination and subsequent protocorm growth differ dramatically. For Dactylorhiza majalis very good growth was observed on medium containing combination of glucose with fructose and on medium containing sucrose (Fig. 4). Slightly worse growth was on fructose and the worst were plants on medium with glucose.

For Oeceoclades decaryana, the media with sucrose and with glucose proved to best ones (Fig. 5). Slightly (but statistically different) worse were the media with fructose and their combination with glucose, but plants developed well under all four treatments. There was dramatic difference from protocorms grown on medium without any sugar. These protocorms on media with no sugar stopped

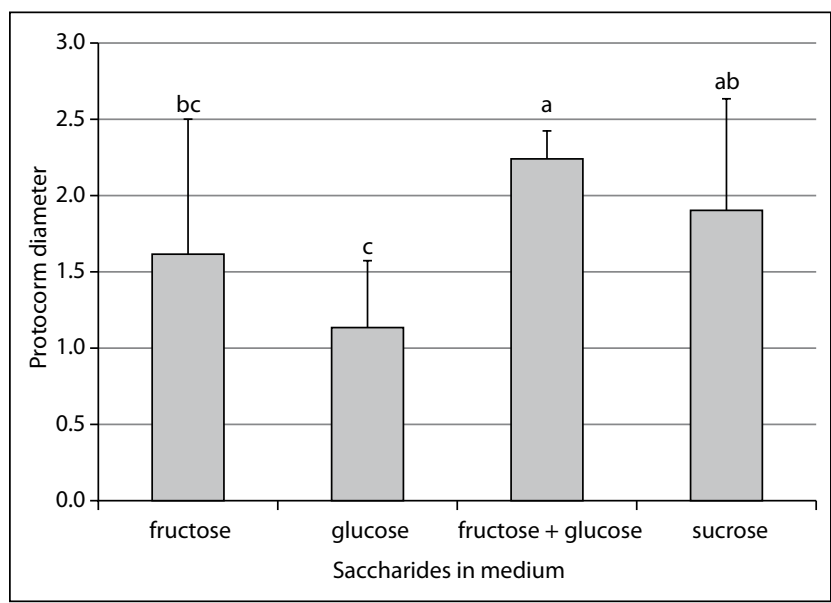

Fig. 4 Effect of different saccharides on Dactylorhiza majalis protocorm growth. Protocorms length $(\mathrm{mm}) 3$ months after sowing (100 $\mathrm{mM}$ hexoses; $50 \mathrm{mM}$ sucrose). Different letters indicate statistically different values at level $a=5 \%$. growth at the testa rupturing stage, but remained alive until the end of the experiment (at least 3 moths). For Ophrys lojaconoi, the best medium was that containing sucrose (Fig. 6). Slightly smaller protocorms developed on medium with glucose. Only very small protocorms developed on medium with combination of fructose and glucose. Nearly all protocorms stopped their growth at early developmental stages and only very few of them grew into bigger size. The medium with fructose as a sole C source gave similar results as the medium without any sugar. The protocorms stopped growth at early stage of swelled embryos, produced some rhizoids and remained alive until the end of the experiment (at least 3 months).

\section{Effect of cytokinins on protocorm growth}

Both tested cytokinins (kinetin and kinetin riboside) gave similar results (Figs. 7 and 8 ). At 18 days after sowing, concentrations 0 to $10 \mathrm{mg} / \mathrm{l}$ lead to nearly same

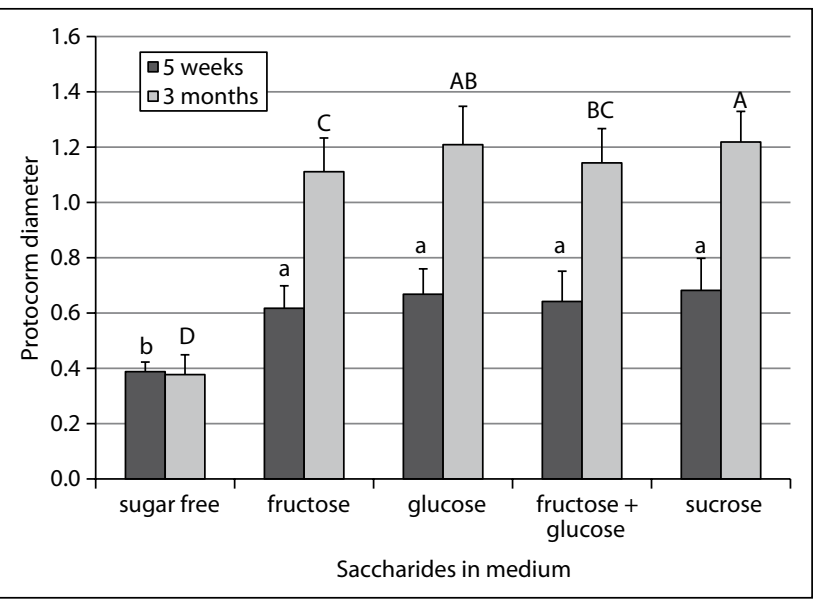

Fig. 5 Effect of different saccharides on Oeceoclades decaryana protocorm growth. Protocorm length $(\mathrm{mm}) 5$ weeks and 3 months after sowing (100 $\mathrm{m} M$ hexoses; $50 \mathrm{mM}$ sucrose). Different letters indicate statistically different values at level $a=5 \%$.

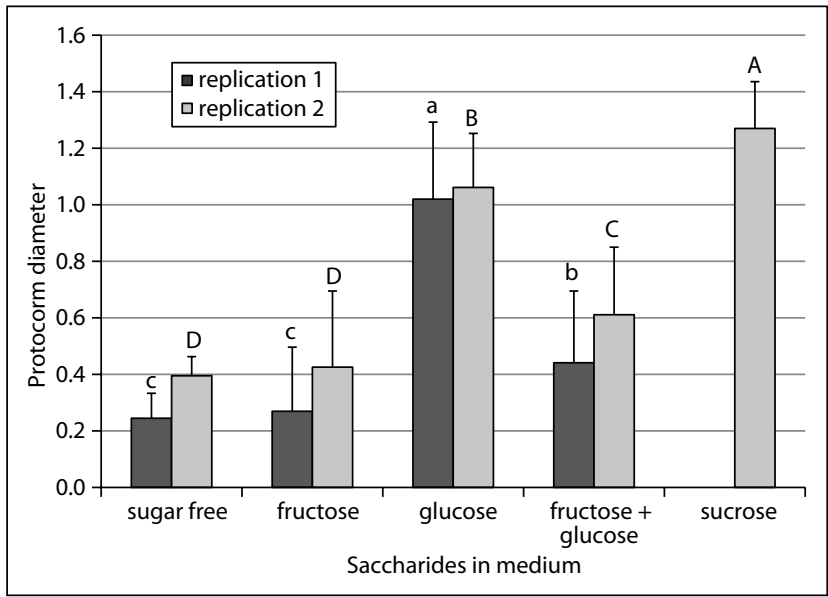

Fig. 6 Effect of different saccharides on Ophrys lojaconoi protocorm growth. Protocorms length $(\mathrm{mm}) 3$ months after sowing $(100 \mathrm{mM}$ hexoses; $50 \mathrm{mM}$ sucrose). Different letters indicate statistically different values at level $a=5 \%$. Two replications for each concentration performed. 

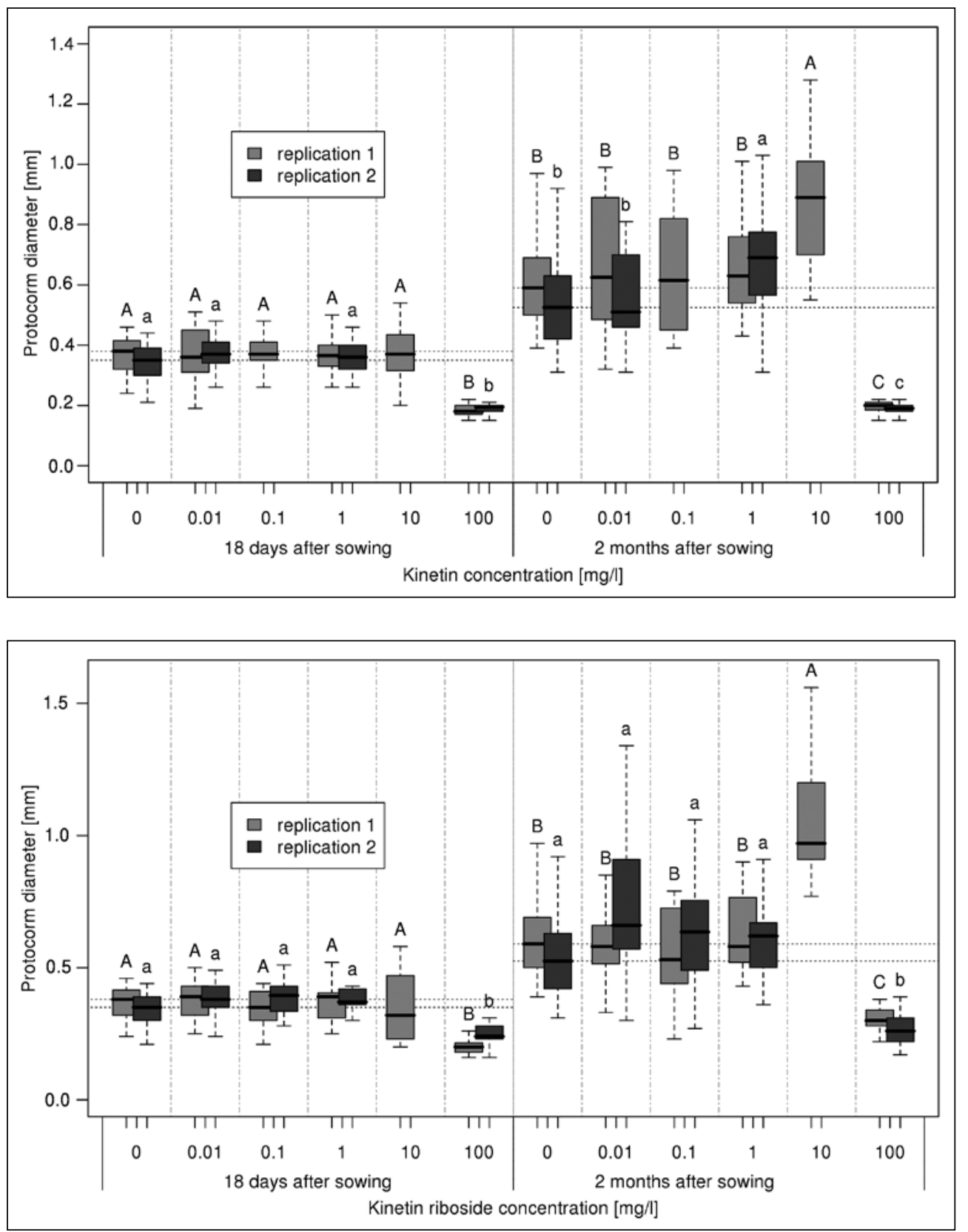

Fig. 7 Effect of kinetin on Dactylorhiza majalis protocorm growth. Length of protocorms after 18 days and 2 months after sowing on media with different concentrations of kinetin. Different letters indicate statistically different values at level $a=5 \%$. Two replication for each concentration performed.

Fig. 8 Effect of kinetin riboside on Dactylorhiza majalis protocorm growth. Protocorms length after 18 days and 2 months after sowing on media with different concentrations of kinetin riboside. Different letters indicate statistically different values at level $a=5 \%$. Two replications for each concentration performed.

protocorm size, while on medium with concentration $100 \mathrm{mg} / \mathrm{l}$, most seeds did not germinate and often no testa rupture could be visible. The seeds that germinated did not grow. Two months after sowing, there were also some differences between lower concentrations. On the media with concentration $10 \mathrm{mg} / \mathrm{l}$, the protocorms were larger than in other treatments, but they showed some developmental abnormalities (mostly more meristematic tips). Differences between remaining concentrations were very small and statistically not significant.

\section{Cultivation in vitro}

Most orchid species growing well on all media. On medium Michl-16, growth was slightly slower, but also very good (data not shown). There were some problems with Dactylorhiza maculata, D. sambucina, and
Neotinea maculata. When cultivated at 23 or $17^{\circ} \mathrm{C}$, their protocorms stopped growing at the size that was used for transplanting. They started to turn brown and consequently died. When transferred to $4{ }^{\circ} \mathrm{C}$, the protocorms also stopped growth, but remain white in a good condition and after this cold treatment started to growth and produced shoots.

Ophrys seedlings experienced other problems under the growing conditions that they were placed in. At $23{ }^{\circ} \mathrm{C}$ they grew well into the stage of first shoot with first leaf but at this stage they did not produce any tuber, turned brown and subsequently died. On the other hand, the plants cultivated at $17^{\circ} \mathrm{C}$ rarely died and most produced tubers and grew into larger plants during subsequent growth periods. According to these results, $23^{\circ} \mathrm{C}$ seems to be too high temperature for shoot and tuber producing phase for these mediterranean plants. Most tu- 

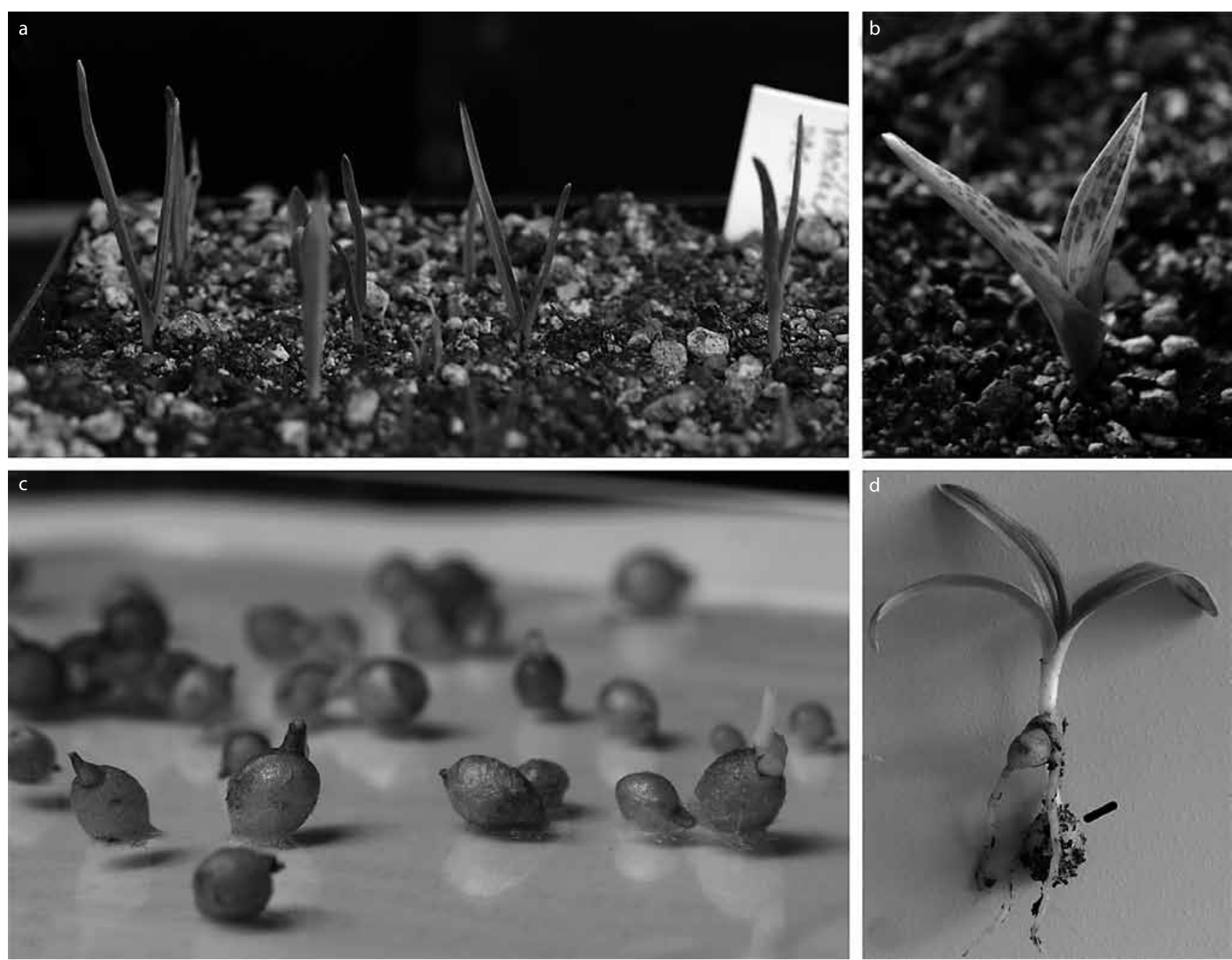

Fig. 9 a) Dactylorhiza maculata s.s. seedlings at their first spring ex vitro, b) Dactylorhiza maculata s.s. after two years ex vitro. c) in vitroproduced Ophrys cilentana tubers ready for planting into soil, d) Ophrys cilentana seedlings after two years ex vitro producing their second tuber (black line). Note relatively long stolon placing new tuber deeper than previous one.

berous species (e.g. Ophrys, Orchis, or Himantoglossum) switched spontaneously to dormancy after new tuber formation and low temperature $\left(\right.$ about $\left.10^{\circ} \mathrm{C}\right)$ stimulated budding.

\section{Deflasking}

\section{Dactylorhiza species}

The seedlings of Dactylorhiza fuchsii, D. incarnata, and $D$. majalis were deflasked at different times the year. These seedlings stopped growth and the smaller ones gradually turned brown and died during the first winter that they were in pots. Seedlings that survived started to grow in the spring, produced new leaves and in a few months had doubled their size. The rate of survival of spring-deflasked seedlings ranged between $0-10 \%$, for the summer-deflasked plants range $=0-20 \%$ and for autumn-deflasked plants survival ranged between $0-22 \%$. All other seedlings (D. baltica, D. bohemica, D. fuchsii, D. incarnata, D. maculata, D. majalis) were deflasked during the end of autumn or early winter to overcome cold period in pots. Nearly all these seedlings (except very small plants without roots and damaged plants) started to growth at early spring with markedly lower losses, the survival rates for these plants were $65-90 \%$.

\section{Ophrys species}

The seedlings of Ophrys lojaconoi and Ophrys cilentana were deflasked at different developmental stages at different times during the year. All deflasked plants stopped growth, their leaves turned brown and all parts except tubers died. Hence, no plant that had not produced tuber in vitro survived. On the other hand, tuber survival rate was $70-90 \%$. These tubers stayed dormant until winter growing season. New leaves were appearing from autumn to early spring and the plants produced new tubers in the same way as mature plants (Fig. 9, survival data not collected). The only exceptions were plants deflasked during late autumn or winter - these plants did not start to grow during their first winter but waited for next cold season with higher losses than summer-deflasked ones (tuber survival rate was about 50\%). 


\section{Glasshouse plant culture}

All tested plants responded well to these conditions with losses were less than one percent per year. List of all species that have been successfully cultivated is in Table 5 .

\section{Discussion}

\section{In vitro culture}

In previously published papers, the composition of different media and the effects of different media on orchids have been presented (see e.g. Rasmussen 1995).
In this study, all orchid species tested grow well on the four different media that were used (Table 8). This contrasts with our earlier work in which MS (Murashige and Skoog 1962) medium (data not shown) had poor results. On the full-strength MS medium Dactylorhiza seeds did not develop protocorms and on the half-strength MS medium they produced only small, very slowly growing plants without any roots, without green shoots that slowly turned brown and died. MS medium have very high salt content in comparison with media that we used with success and it is possible that this might be the problem. Negative impact of medium salinity on orchid growth was reported previously (Harbeck 1968) and Harbeck assumed that low medium molarity is crucial for Dacty-

Table 8 Media composition

\begin{tabular}{|c|c|c|c|c|c|}
\hline & & Mo2 & $1 / 4-2$ & $\begin{array}{l}\text { Michl-15 } \\
\text { for germination }\end{array}$ & $\begin{array}{l}\text { Michl-16 } \\
\text { for growing }\end{array}$ \\
\hline \multirow{7}{*}{ Macronutrients (g/l) } & $\mathrm{KH}_{2} \mathrm{PO}_{4}$ & 0.073 & 0.043 & 0.216 & 0.216 \\
\hline & $\mathrm{KCl}$ & & & 0.150 & 0.150 \\
\hline & $\mathrm{MgSO}_{4} \cdot 7 \mathrm{H}_{2} \mathrm{O}$ & 0.077 & 0.093 & 0.246 & 0.246 \\
\hline & $\mathrm{CaCl}_{2}$ & 0.057 & 0.083 & 0.022 & 0.022 \\
\hline & $\mathrm{NH}_{4} \mathrm{NO}_{3}$ & 0.033 & 0.413 & & 0.166 \\
\hline & $\left(\mathrm{NH}_{4}\right)_{2} \mathrm{SO}_{4}$ & & & & \\
\hline & $\mathrm{KNO}_{3}$ & 0.038 & 0.475 & & \\
\hline \multirow{12}{*}{ Micronutrients (mg/l) } & $\mathrm{Na}_{2}$ EDTA & 10.00 & 10.00 & & 17.50 \\
\hline & $\mathrm{FeSO}_{4} \cdot 7 \mathrm{H}_{2} \mathrm{O}$ & 7.00 & 7.00 & & 30.00 \\
\hline & $\mathrm{H}_{3} \mathrm{BO}_{3}$ & & & & 1.01 \\
\hline & $\mathrm{ZnSO}_{4} \cdot 7 \mathrm{H}_{2} \mathrm{O}$ & 2.20 & 2.20 & & 1.01 \\
\hline & $\mathrm{MnCl}_{2} \cdot 4 \mathrm{H}_{2} \mathrm{O}$ & & & & 0.13 \\
\hline & $\mathrm{CuSO}_{4} \cdot 5 \mathrm{H}_{2} \mathrm{O}$ & 0.01 & 0.01 & & 0.03 \\
\hline & $\mathrm{NiCl}_{2} \cdot 6 \mathrm{H}_{2} \mathrm{O}$ & & & & 0.03 \\
\hline & $\left(\mathrm{NH}_{4}\right)_{6} \mathrm{Mo}_{7} \mathrm{O}_{24}$ & & & & 0.03 \\
\hline & $\mathrm{CoCl}_{2}$ & 0.00 & 0.00 & & 0.02 \\
\hline & $\mathrm{Na}_{2} \mathrm{MoO}_{4} \cdot 2 \mathrm{H}_{2} \mathrm{O}$ & 0.06 & 0.06 & & \\
\hline & $\mathrm{MnSO}_{4} \cdot \mathrm{H}_{2} \mathrm{O}$ & 4.20 & 4.20 & & \\
\hline & $\mathrm{KI}$ & 0.20 & 0.20 & & \\
\hline \multirow{4}{*}{$\begin{array}{l}\text { Organic supplements } \\
(\mathrm{g} / \mathrm{l})\end{array}$} & ananas juice & 20 & 20 & & \\
\hline & casein hydrolysate & 1.0 & 1.0 & 0.5 & 0.5 \\
\hline & pangamin & 0.90 & 0.45 & & \\
\hline & yeast extract & & & 0.5 & 0.5 \\
\hline \multirow{3}{*}{ Vitamins (mg/l) } & thiamine & 0.1 & 0.1 & 1.0 & 1.0 \\
\hline & pyridoxine & 0.1 & 0.1 & 1.0 & 1.0 \\
\hline & nikotinamide & 0.1 & 0.1 & 1.0 & 1.0 \\
\hline Phytohormones (mg/l) & kinetine & 2.0 & 2.0 & & \\
\hline \multirow{3}{*}{$\begin{array}{l}\text { Other organic } \\
\text { compounds (mg/l) }\end{array}$} & citric acid & & & 192.0 & 192.0 \\
\hline & glycine & 0.4 & 0.5 & & \\
\hline & inositol & 20.0 & 25.0 & & \\
\hline Saccharides (g/l) & sucrose & 10.0 & 15.0 & 10.0 & 30.0 \\
\hline \multirow{3}{*}{ Others $(\mathrm{g} / \mathrm{l})$} & activated charcoal & 0.5 & 0.5 & 1.2 & 1.2 \\
\hline & agar & 7.0 & 7.0 & 8.0 & 15.0 \\
\hline & $\mathrm{pH}$ & 5.8 & 5.8 & 5.8 & 5.8 \\
\hline
\end{tabular}


lorhiza germination as it ensures sufficient moisture. Our medium 1/4-2 has similar salt ratio as MS medium but at one-quarter strength and is supplemented with casein hydrolysate, pangamin, activated charcoal and pineapple juice. Based on the studies reported here, we are not able to determine what is responsible for the differing results with different media, but we now have identified four media suitable for European terrestrial orchid cultivation. It is, however, important to test these media for other temperate terrestrial orchids to determine their overall suitability.

Temperature is an important factor in the cultivation of some species. Plants are often said to be successfully grown at "laboratory temperature" around $25^{\circ} \mathrm{C}$. When we were at beginning of our work with terrestrial orchids, we tried to cultivate some Ophrys and Dactylorhiza seedlings at this temperature without any success. The plants turned brown and died relatively rapidly (data not shown). The harmful effects of high temperatures were referred also by Haas (1977). For this reason we worked only at lower temperatures 23,17 , and $2{ }^{\circ} \mathrm{C}$. All plants grew well at $17^{\circ} \mathrm{C}$, but at $23^{\circ} \mathrm{C}$ some had problems with growth and Ophrys plants did not produce tubers. Moreover, three tested plants required cold period at $2{ }^{\circ} \mathrm{C}$ for successful subsequent growth in vitro and all Dactylorhi$z a$ species for growth ex vitro. This is in agreement with previous results of Borris (1970), Hadley (1970), Beyrle et al. (1987), and Rasmussen (1995) who all reported Dactylorhiza seedlings requirement for vernalization. It is possible that these temperate plants are better growing at lower temperatures than their tropical relatives as previously reported by Malmgren (2011) and that proper temperature changes can be in some species at least as important as culture media composition. The Mediterranean species grow during cold period of year and it is possible, that growth of these plants can be driven by temperature changes. Mature plants start their growth at autumn when temperature drops down and the greenhouse-grown plants are often reported to wait for low temperatures and are not able to grow successfully in invariably warm conditions (e.g. Cribb and Bailes 1989). Maybe seedlings of these plants have similar demands, too.

\section{Ethanol treatment}

Orchid seed disinfection is still a process that requires further testing and elaboration as result are something mysterious with many different approaches. Some authors use ethanol and others do not, but reports about the importance of this step are sparse. Ethanol is able to wash out some hydrophobic substances as waxes. Seeds become easily soaked and less hydrophobic which leads to better manipulation with them. Our results indicate that short ethanol treatment can have positive effect but longer application can kill the seeds. From many other reports with different orchid species it is obvious that different species can have very different requirements for disinfection and that 2 minutes which seems optimal for Anacamptis morio in our experiment must not be optimal in other species.

\section{Hypochlorite disinfection}

Disinfection is often using to increase orchid seeds germination rate, perhaps due to breakdown of the seed testa. Both natrium and calcium hypochlorites are used, but with different results. Natrium hypochlorite is often use because it is easily available as commercial solution, but if compared, calcium hypochlorite gives often better results with germination (Rasmussen 1995 and references therein). The cause of this observation, however, has not been satisfactorily explained yet. Natrium hypochlorite solution is stronger oxidizing agent with higher $\mathrm{pH}$ $\left(\mathrm{pH}(\mathrm{NaOCl}) \sim 12.5, \mathrm{pH}\left(\mathrm{Ca}(\mathrm{OCl})_{2}\right) \sim 11.5\right)$. Another oxidizing agent hydrogen peroxide seems to be harmful to the seeds without positive effect on germination (Lucke 1978; Van Waes 1984; Rasmussen 1995), while sodium hydroxide, a strong base, is able to promote seed germination (Eiberg 1970). Effect of $\mathrm{pH}$ is expected to be responsible for different effects of hypochlorites (Rasmussen 1995). In our experiments, careful determination of actual hypochlorite concentrations enabled to compare the effect of both agents under standard conditions. We confirmed marked differences depending on the particular orchid species. Series of experiments with $\mathrm{pH}$ adjusted hypochlorite solutions had been made. The experiments revealed different effects of $\mathrm{pH}$ when the same concentrations of both types of hypochlorite were maintained. The results, however, are heterogeneous, which is probably caused by instability of the solutions after $\mathrm{pH}$ adjustment, and thus the issue require further study.

\section{Sugar effect}

Different media published previously for orchid in vitro cultures contained mostly sucrose, but in some cases also fructose or glucose supply was reported (see e.g. Michl 1988; Rasmussen 1995). Three species tested in our experiments responded differently to different sugar sources. For Oeceoclades decaryana, sucrose, glucose and fructose seemed to be very good energy sources. Dactylorhiza majalis grew slightly worse on fructose and very badly on glucose. On the other hand, the very good growth occurred on medium with combination of glucose and fructose. These results need other investigation for explanation, but hexoses seem not to be optimal C source for this species. Ophrys lojaconoi grew well on sucrose, slightly worse on glucose and very badly on fructose or its combination with glucose. Many protocorms on fructosecontaining medium remained in early developmental stages and seemed not to be able to grow further. This could be explained by possible fructose inhibitory effect on young developmental stages of protocorm development, but other investigation is needed. Our results show 
that sugar source can have important effect on protocorm development and that hexoses can have inhibitory effect in some species. Previously published results with tropical species showed ability to grow on glucose, fructose and sucrose (Knudson 1924; LaGarde 1929; Ernst et al. 1971). Some other reports show better growth on fructose than on glucose (Burgeff 1936; Arditti 1967; Ernst 1967). All these tropical species belong to subfamily Epidendroideae similarly as Oeceoclades decaryana tested in our experiments that grew relatively well on all tested sugars. Other two species that we tested belong to subfamily Orchidoideae that have not been investigated yet for sugar utilization. These species show rapid inhibition on media with some hexoses - glucose in Dactylorhiza and fructose in Ophrys. It is possible that these two developmental groups have different sugar requirements. Experiments are running now to resolve these questions.

\section{Effect of cytokinins}

Many researches working with orchids use different cytokinines to promote growth of different species (e.g. Harvais 1972; Chen and Piluek 1995) or germination of Cypripedium (Harvais 1982; Van Waes and Debergh 1986b; Steele 1996) and Epipactis (Van Waes and Debergh 1986b). On the other hand no cytokinin effect on Dactylorhiza maculata germination have been shown (Van Waes and Debergh 1986b). This is in accordance with our results with Dactylorhiza majalis where no differences were found between concentrations 0 to $1 \mathrm{mg} / \mathrm{l}$ of kinetin or kinetin riboside. However, on medium with $10 \mathrm{mg} / \mathrm{l}$ of either kinetin or kinetin riboside the protocorms were larger after two months of growth comparing to other variants, while germination was not affected. Concentrations $100 \mathrm{mg} / \mathrm{l}$ are probably toxic because no protocorm growth or germination was observed. It is possible, that concentrations used previously by Van Waes and Debergh (1986b) for Dactylorhiza maculata were not sufficient for promoting growth similarly as concentrations lower than $10 \mathrm{mg} / \mathrm{l}$ used in our experiments.

\section{Conclusions}

In the presented work, we summarize the knowledge gained during a decade of study of sowing and cultivation of European terrestrial orchids. We provide evidence that many species can be successfully grown in long-term pot cultures in a greenhouse, providing that requirements of optimum water regime and temperature fluctuations during a year (depending on plant phenophase) are ensured. For most species tested, the in vitro sowing was successful, nevertheless there are species for which we obtained only minimum of protocorms (Pseudorchis albida, Neottinea ustulata) or no protocorms at all (Epipactis helleborine). Clarifying barriers of germination in these species will be the aim of further research. Where germination was successful, the seedlings could be relatively easily cultivated in vitro. However, it is necessary to respect plant phenological cycles and adjust the cultivation conditions (especially temperature) accordingly. The transfer into ex vitro conditions was successful especially if the plants had formed sufficiently strong tubers. We have not confirmed the necessity of symbiotic fungus infections, mentioned in many previous studies. Based on our experience we can state that the cultivation of selected species of European orchids is very feasible and can be applied for example for conservation of endangered endemic genotypes of many species (especially of the genus Ophrys and Dactylorhiza), which are acutely threatened by extinction.

\section{Acknowledgements}

Many thanks to Dr. Jaroslav Mácha for helpful discussions about orchid sowing, Union for Transport and Signaling of Plants (UTSR) for complete support and two anonymous reviewers for helpful comments.

\section{REFERENCES}

Arditti J (1967) Factors affecting the germination of orchid seeds. The Botanical Review 33: 1-97.

Barroso J, Fevereiro P, Oliveira MM, Pais MSS (1990) In vitro seed germination, differentiation and production of minitubers from Ophrys lutea Cav., Ophrys fusca Link and Ophrys speculum Link. Scientia Horticulturae 42: 329-37.

Beyrle H, Penningsfeld F, Hock B (1987) Die Gärtnerische Aufzucht von feuchtigkeitsliebenden Dactylorhiza-arten. Die Orchidee 38: 302-306.

Borris H (1970) Vermehrung europäischen Orchideen as Samen. Der Erwerbsgärtner 24: 349-351.

Borris H, Albrecht L (1969) Rationelle Samenvermehrung and Anzucht europäischer Erdorchideen. Gartenwelt 69: 511-513.

Burgeff H (1936) Samenkeimung der Orchideen und Entwicklung ihrer Keimpflanzen. Verlag von Gustav Fischer, Jena, Germany.

Cribb P, Bailes Ch (1989) Hardy Orchids - Orchids for the Garden and Frost-free Greenhouse. Timber Press, Portland, Oregon, USA.

Eiberg H (1970) Asymbiotisk frøspiring og kulturforsøg hos nogle europæiske jordorkideer. Thesis, University of Copenhagen: Plant Physiological Laboratory. In: Rasmussen (1995)

Ernst R (1967) Effect of carbohydrate selection on the growth rate of freshly germinated Phalaenopsis and Dendrobium seed. American Orchid Society Bulletin 36: 1068-1073.

Ernst R, Arditti J, Healey PL (1971) Carbohydrate physiology of orchid seedlings. II. Hydrolysis and effects of oligosaccharides. American Journal of Botany 58: 827-835.

Frosh W (1982) Beseitigung der durch die innere Hülle bedingten Keimhammung bei europäischen Orchideen. Die Orchidee 33: $145-146$.

Galunder R (1986) Der Einfluss von Brauereihefe auf die Keimung von mitteleuropäischen Erdorchideen. Die Orchidee 37: 135-137.

Haas NF (1977) Asymbiotische Vermehrung europäischer Erdorchideen I. Dactylorhiza sambucina (L.) Soó. Die Orchidee 28: 27-31. 
Hadley G (1970) The interaction of kinetin, auxin and other factors in the development of North temperate orchids. New Phytologist 69: 549-555.

Hadley G (1982) European terrestrial orchids. In: Arditti J (ed) Orchid Biology. II. Reviews and perspectives. Orchid seed germination and seedling culture - a manual. Cornell University Press, Ithaca, New York, USA.

Harbeck M (1968) Versuche zut Samenvermehrung einiger Dactylorhiza-Arten. Jehresbericht der naturwissenschaftlichen Vereins in Wuppertal 21/22: 112-118.

Harvais G (1982) An improved culture medium for growing the orchid Cypripedium reginae axenically. Canadian Journal of Botany 60: 2547-2555.

Ježek Z (1996) Na lovu mexických orchidejí. Moravské vydavatelství Květen, Brno, CZ, pp 122-127.

Knudson L (1924) Further observations on nonsymbiotic germination of orchid seeds. The Botanical Gazette 77: 212-219.

Kramer C (1956) Extension of Multiple Range Tests to Group Means with Unequal Numbers of Replications. Biometrics 12: 307-310.

Kruskal W H, Wallis W A (1952) Use of Ranks in One-Criterion Variance Analysis. Journal of the American Statistical Association 47: 583-621.

LaGarde RV (1929) Non-symbiotic germination of orchids. Annals of the Missouri Botanical Garden 16: 499-514.

Lucke E (1971) Zur Samenkeimung mediterraner Ophrys. Die Orchidee 22: 62-65.

Lucke E (1978) Fragen zur aseptischen Samenernte bzw. Desinfektion der Orchideensamen. Die Orchidee 29: 42-43.

Malmgren S (1989) Fröförökning (4). Orchidéer 10: 154-157.

Malmgren S, Nyström H (2011) Orchid Propagation. http://www .lidaforsgarden.com/Orchids/engelsk.htm. Accessed 5 April 2011.

Michl J (1988) Standardizovaná metoda množení evropských orchidejí semeny II. Živa 3: 89-91.

Muir HJ (1989) Germination and mycorrhizal fungus compatibility in European orchids. In: Pritchard HW (ed) Modern methods in orchid conservation. Cambridge University Press, Cambridge, pp 39-56.

Murashige T Skoog F (1962) A revised medium for rapid growth and bio-assays with Tobacco tissue cultures. Physiologia Plantarum 15: 473-497.

Ponert J (2009) Early Stages of Development of Terrestrial Orchids: the Effect of Saccharides and Phytohormones. Diploma thesis, Charles University, Prague.

Pritchard HW (1985) Determination of orchid seed viability using fluorescein diacetate. Plant, Cell and Environment 8: 727-730.

R Development Core Team (2009) A Language and Environment for Statistical Computing. R Foundation for Statistical Computing, Vienna, Austria.

Rasmussen HN (1995) Terrestrial orchids, from seed to mycotrophic plant. Cambridge University Press, Cambridge.

Rasmussen HN, Andersen TF, Johansen B (1990) Light stimulation and darkness requirement for the symbiotic germination of Dactylorhiza majalis in vitro. Physiologia Plantarum 79: 226-230.

Rasmussen HN, Rasmussen FN (1991) Climatic and seasonal regulation of seed plant establishment in Dactylorhiza majalis inferred from symbiotic experiments in vitro. Lindleyana 6: 221-227.

Rasmussen HN, Rasmussen FN (2009) Orchid mycorrhiza: implications of a mycophygous life style. Oikos 118: 334-345.

Sekerka P, Obdržálek J, Ponert J (2007) Plejonky a další chladnomilné orchideje. Grada Publishing, Prague, CZ.

Steele WK (1996) Large Scale Seedling Production of North American Cypripedium Species. In: Allen C (ed) North American Native Terrestrial Orchids - Propagation and Production, Conference Proceedings, The North American Native Terrestrial Orchid Conference, pp 11-26.

Van Waes J (1984) In vitro studie van de kiemingsfysiologie van Westeuropese orchideën. Thesis, Rijkuniversiteit Gent. In: Rasmussen (1995).

Van Waes JM, Debergh PC (1986a) Adaptation of the tetrazolium method for testing the seed viability and scanning electron microscopy of some Western European orchids. Physiologia Plantarum 66: 435-442.

Van Waes JM, Debergh PC (1986b) In vitro germination of some Western European orchids. Physiologia Plantarum 67: 253-261.

Vermeulen P (1947) Studies on Dactylorchids. Utrecht: Schotanus and Jens. In: Rasmussen (1995).

Veyret Y (1969) La structure des semences des orchidaceae et leur aptitude a la germination in vitro en cultures pures. Musée d'Histoire Naturelle de Paris, Travaux du Laboratoire La Jaysinia 3: 89-98. 